\title{
The Canadian Academy of Health Sciences: coming of age at the right time
}

\section{Martin T. Schechter MD, Paul W. Armstrong MD}

$\mathrm{D}$ o vaccines cause autism? How much vitamin D should Canadians be taking? How can we reform our health care system to care for the coming avalanche of elderly citizens with comorbid chronic diseases? How much should we be spending on the last roo days of life? Are we ready for a new bioterrorism threat? How do we best accommodate the promise of stem-cell research in an ethical and just framework?

There is no shortage of thorny and pressing issues continually emerging in the complex world of health and health care. Such issues need careful and thoughtful analysis that is not only expert, but also unbiased and independent of vested interests and agendas. They call for an objective weighing of the available scientific evidence at arm's length from political considerations and with a focus on the public interest.

When the president and Congress of the United States want objective advice on such urgent health issues, they call on the Institute of Medicine. ${ }^{1}$ When the prime minister and Parliament of the United Kingdom require similar counsel, they turn to the Academy of Medical Sciences. ${ }^{2}$ But when the prime minister, premiers and legislators of Canada want similar advice, who can they call? Until recently, no organization existed in Canada to respond, but that has now been addressed with the formation of the Canadian Academy of Health Sciences. ${ }^{3}$

Founded in 2004, ${ }^{4}$ the Canadian Academy of Health Sciences has elected about 260 fellows ${ }^{5}$ through a rigorous peerreview process that recognizes those who have demonstrated leadership, creativity and distinctive competencies in health science in Canada. In this way, the Canadian Academy of Health Sciences joins the Royal Society of Canada, which has long honoured Canadians for their accomplishments in the natural sciences, social sciences and humanities, and the Canadian Academy of Engineering, which recognizes achievements in the engineering sciences.

A unique aspect of the Canadian Academy of Health Sciences, relative to international comparators, is that its fellows span the full breadth of academic health science, from fundamental science to social science and population health; they also represent the full spectrum of health disciplines, including nursing, dentistry, veterinary medicine, rehabilitation sciences, pharmaceutical sciences, medicine and related fields such as psychology, health law, ethics and health economics. Hence the Canadian Academy of Health Sciences is truly ecumenical and well disposed to provide a holistic perspective on health-related matters.

Canada now joins many other countries, including all of the G7 nations, that have long supported like-minded health

\section{Key points}

- The complex issues that arise in health and health care require expert analysis that is unbiased, independent of vested interests, conducted at arm's length from political considerations and, in some instances, rapid.

- Modelled after the Institute of Medicine in the United States, the Academy of Medical Sciences in the United Kingdom and other academies, the recently formed Canadian Academy of Health Sciences is ready to fill this unmet need in Canada.

- By electing fellows whose competencies span the full breadth of health and all health-related disciplines, the Canadian Academy of Health Sciences is ideally suited to address complex health challenges from a multidisciplinary perspective.

- The Canadian Academy of Health Sciences is not an advocacy organization. Its fellows are leaders who have made significant lifetime contributions to the health of Canadians and volunteer their expertise and experience to address the major health challenges we face.

science organizations. All of the academies listed in Table I provide critical advice on health issues in their home countries. For example, reports on quality of care $^{11}$ by the Institute of Medicine focused national and international attention on the crucial area of medical errors and had a major impact on procedures to enhance patient safety. A report by the Academy of Medical Sciences ${ }^{10}$ provided the United Kingdom with pivotal recommendations for striking the right balance between the need for data to support vital medical research and the responsibility to protect patient privacy.

All of these academies are supported to varying degrees by government funding, private sponsorship, charitable donations and membership fees. And all of them are members of the InterAcademy Medical Panel, a global network of 65 national academies of science and medicine whose goal is "to strengthen the role of all academies to alleviate the health burdens of the world's poorest people; build scientific capacity for health; and provide independent scientific advice on promoting health science and health care policy to national governments and global organizations." ${ }^{12}$ With the Canadian Academy of Health Sciences joining the Interacademy Medical Panel, Canada is at last engaged in this important global alliance.

Martin Schechter is with the Department of Health Care and Epidemiology, University of British Columbia, Vancouver, BC. Paul Armstrong is with the Department of Medicine, University of Alberta, Edmonton, Alta. 
The Canadian Academy of Health Sciences should be distinguished from a related entity that provides advice to the federal government, that is, the recently formed Council of Canadian Academies. Formed in 2005, this council is a separate entity, under contract with Industry Canada to provide 50 assessments over the next Io years across the entire spectrum of potential questions. By way of illustration, current council topics include groundwater in Canada, gas hydrates as an energy resource and nanotechnology; only a few topics are directly health related. The Canadian Academy of Health Sciences is committed to working in partnership with the Council of Canadian Academies in areas of mutual interest. Indeed, true collaboration involving the Canadian Academy of Health Sciences, the Royal Society of Canada, the Canadian Academy of Engineering and the Council of Canadian Academies, as occurs among the National Academies of Science in the United States and in many other countries, would create a tremendous resource for the benefit of all Canadians. We hope that such an integrated model will evolve from the current structure over time.

Health and health care in the 2Ist century are and will continue to be increasingly complex and challenging spheres requiring careful attention and, in many instances, assessments specific to the Canadian context. The Canadian Academy of Health Sciences is positioned to address the many pressing health-related questions in response to the needs of a wide range of sponsors within federal departments and provincial governments as well as nongovernmental organizations and the private sector.

The Canadian Academy of Health Sciences is not an advocacy organization promoting the interests of any professional group or sector. Its objectives (Box I) are to serve voluntarily in the public interest. The election process for fellowship se-
Box 1: Objectives of the Canadian Academy of Health Sciences

- Serve as a credible, expert and independent assessor of science and technology issues relevant to the health of Canadians

- Support the development of timely, informed and strategic advice on urgent health issues

- Support the development of sound and informed public policy related to these issues

- Enhance understanding of health-related science and technology issues affecting the public good by disseminating the results of assessments and providing opportunities for public discussion of these matters

- Provide a single authoritative and informed voice for the health science communities

- Monitor global health-related events to enhance Canada's state of readiness for the future

- Represent Canadian health sciences internationally and liaise with similar international academies to enhance understanding and potential collaborations on matters of mutual interest

lects those who have made significant lifetime contributions to the health of Canadian society and have a covenant to serve by contributing their advice, expertise and experience to the urgent challenges we face.

The fundamental importance of independence, both financial and scientific, was underscored in an address to the academy's 2006 Annual General Meeting by Dr. Kenneth Shine, former president of the Institute of Medicine. $.^{13} \mathrm{Al}-$ though those who fund Canadian Academy of Health Sciences scientific assessments (e.g., governments, nongovern-

Table 1: Health science academies in the G7 countries

\begin{tabular}{|c|c|c|c|c|c|}
\hline Country & Academy & $\begin{array}{c}\text { Year } \\
\text { founded }\end{array}$ & $\begin{array}{l}\text { No. of } \\
\text { members }\end{array}$ & Website & Selected recent report \\
\hline Canada & $\begin{array}{l}\text { Canadian Academy of Health } \\
\text { Sciences }\end{array}$ & 2004 & 260 & www.cahs-acss.ca & $\begin{array}{l}\text { The return on investments in } \\
\text { health research: defining the } \\
\text { best metrics } †\end{array}$ \\
\hline France & $\begin{array}{l}\text { Académie Nationale } \\
\text { de Médecine }\end{array}$ & 1820 & 430 & www.academie-medecine.fr & $\begin{array}{l}\text { Human papillomavirus vaccines: } \\
\text { their place in the prevention of } \\
\text { cervical cancer }\end{array}$ \\
\hline Germany & $\begin{array}{l}\text { Deutsche Akademie der } \\
\text { Naturforscher Leopoldina }\end{array}$ & 1652 & $1250^{*}$ & $\begin{array}{l}\text { www.leopoldina-halle.de/cms } \\
\text { /en.html }\end{array}$ & $\begin{array}{l}\text { Statement on stem cell } \\
\text { research in Germany }\end{array}$ \\
\hline Italy & $\begin{array}{l}\text { Accademia Nazionale } \\
\text { di Medicina }\end{array}$ & 1991 & 350 & www.accmed.org & $\begin{array}{l}\text { Task force recommendations on } \\
\text { the treatment of postoperative } \\
\text { pain }^{8}\end{array}$ \\
\hline Japan & Science Council of Japan & 1949 & $2210^{*}$ & www.scj.go.jp/en/index.html & $\begin{array}{l}\text { Avian influenza and infectious } \\
\text { diseases }\end{array}$ \\
\hline $\begin{array}{l}\text { United } \\
\text { States }\end{array}$ & Institute of Medicine & 1970 & 1689 & www.iom.edu & $\begin{array}{l}\text { To err is human: building a } \\
\text { safer health system }{ }^{11}\end{array}$ \\
\hline
\end{tabular}

*The German and Japanese academies combine health sciences with the natural and social sciences.

†ln progress. 
mental organizations, private industry) have an important say in defining study questions, they cannot influence the outcomes. Panel members are recommended by the academy's Standing Committee on Assessments and approved by its board. All reports are peer reviewed by independent reviewers selected by the academy, with final reports approved by the board. Throughout the process, scrupulous attention is paid to the avoidance of conflict of interest.

Challenges remain for the academy to realize its vision fully. These include securing unfettered multisectoral financial support that ensures independence from vested interests; building a versatile and expert infrastructure to facilitate the conduct of unbiased assessments and other activities; demonstrating impact through a strong and meaningful track record of products and achievements as the Institute of Medicine in the United States has done; developing strong partnerships with key organizations in Canada and abroad; and engaging more fully in assessments and forecasting of health issues on a global scale. Much progress has already been made on many of these fronts, but fully addressing these challenges will not be easy. Clearly communicating and promoting the independent, nonadvocacy, voluntary and multidisciplinary nature of the academy is key to its future. Sponsorship of assessments by diverse interested parties - private foundations, corporate philanthropy and arm's length governmental funding - is critical to establishing the academy as a strong and independent provider of objective scientific advice. For example, more than 20 organizations, both national and provincial, have joined to sponsor the academy's first major assessment: defining the best metrics for the return on investments in health research. An outstanding panel of I4 international experts chaired by Dr. Cyril Frank has this work well underway, and the completion and dissemination of its report later this year will be a benchmark for the future of the academy. Several other working groups are currently developing assessment plans to address a number of pressing health issues facing Canada.

The collective wisdom and experience of the fellows is a resource whose value is incalculable. They are without doubt the academy's greatest treasure. Independence and objectivity are by far its most important characteristics. The Canadian Academy of Health Sciences is a new, unique and distinctly Canadian health advisory body that can and will make a dif- ference to the health of all Canadians, by evaluating the science, weighing the evidence and telling the truth.

This article has been peer reviewed.

Competing interests: Dr. Schechter is President of the Canadian Academy of Health Sciences, and Dr. Armstrong is Past-President.

Contributors: Both authors made substantial contributions to conceiving the article, drafting it and revising it critically for important intellectual content. Both authors saw and approved the final version.

\section{REFERENCES}

I. About the Institute of Medicine: advising the nation, improving health. Washing ton (DC): The National Academies; 2006. Available: www.iom.edu/Object.File /Master/36/93I/IOM-BROCHURE-FINAL.pdf (accessed 2008 Feb 6).

2. About us. London (UK): Academy of Medical Sciences. Available: www.acmedsci .ac.uk/p29.html (accessed 2008 Feb 6).

3. About CAHS. Ottawa: Canadian Academy of Health Sciences; 2006. Available: www.cahs-acss.ca/e/about/ (accessed 2008 Feb 6).

4. Armstrong PW, Dempster LJ, Hawkins DG, et al. The birth of the Canadian Academy of Health Sciences. Clin Invest Med 2005; 28:43-5.

5. Fellowships. Ottawa: Canadian Academy of Health Sciences. Available: www.cahs -acss.ca/e/fellowships/currentfellows.php (accessed 2008 Feb 6).

6. Bégué $\mathrm{P}$, Henrion $\mathrm{R}$, Blanc $\mathrm{B}$, et al. Les vaccins des papillomavirus humains : leur place dans la prévention du cancer du col utérin. Paris : Academie Nationale de Médecine; 2007. Available: www.academie-medecine.fr/Upload/begue_rapp _IIdec_2008I.doc (accessed 2008 Feb I2).

7. Presidium of the German Academy of Sciences Leopoldina. Statement on stem cell research in Germany. Halle/Saale (Germany): Deutsche Akademie der Naturforscher Leopoldina; 2007. Available: www.leopoldina-halle.de/cms/fileadmin /user_upload/leopoldina_downloads/StemCells.pdf (accessed 2008 Feb I2).

8. Braschi A, Caballoro F, Allegri M. Il trattamento del dolore post-operatorio: raccomandazioni di un gruppo di esperti. Genova (Italy): Accedemia Nazionale di Medicina; 2007.

9. Joint science academies' statement: avian influenza and infectious diseases. Tokyo: Science Council of Japan; 2007. Available: www.scj.go.jp/ja/info/kohyo /pdf/kohyo-20-s2.pdf (accessed 2008 Feb I2).

Io. Personal data for public good: using health information in medical research. London (UK): Academy of Medical Sciences; 2006. Available: www.acmedsci.ac.uk /p48prid5.html (accessed 2008 Feb 29).

II. Kohn LT, Corrigan JM, Donaldson MS, editors. To err is human: building a safer health system. Washington (DC): Committee on Quality of Health Care in America, Institute of Medicine, National Academy Press; I999.

I2. Welcome to IAMP: the health network of academies of science and medicine. Trieste (Italy): Interacademy Medical Panel. Available: www.iamp-online.org (accessed 2008 Feb 6).

I3. Sibbald B. New health academy must be financially independent. CMAJ 2006; 175 : II93-4.

Correspondence to: Dr. Martin T. Schechter, Faculty of Medicine, University of British Columbia, 5804 Fairview Ave., Vancouver BC V6T IZ3; fax 604 822-4994; martin.schechter@ubc.ca 